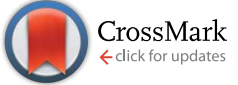

Cite this: Chem. Sci., 2016, 7, 5821

\title{
Thin film transfer for the fabrication of tantalum nitride photoelectrodes with controllable layered structures for water splitting $\dagger$
}

\author{
Chizhong Wang, ${ }^{a}$ Takashi Hisatomi, ${ }^{\text {ab }}$ Tsutomu Minegishi, ${ }^{\text {abc }}$ Mamiko Nakabayashi, ${ }^{d}$ \\ Naoya Shibata, ${ }^{d}$ Masao Katayama ${ }^{a b}$ and Kazunari Domen*ab
}

The fabrication of semiconductor films on conductive substrates is vital to the production of highperformance electrodes for photoelectrochemical (PEC) water splitting. In this work, a thin film transfer method was developed to produce $\mathrm{Ta}_{3} \mathrm{~N}_{5}$ film photoanodes for PEC water oxidation. Phase-pure $\mathrm{Ta}_{3} \mathrm{~N}_{5}$ thin films were formed on inert Si substrates via magnetron sputtering of Ta films, followed by oxidation and subsequent nitridation in a flow of gaseous $\mathrm{NH}_{3}$. The resulting porous $\mathrm{Ta}_{3} \mathrm{~N}_{5}$ films were uniformly transferred from the Si substrates using metallic layers that allowed ohmic contact at the $\mathrm{Ta}_{3} \mathrm{~N}_{5}$ film/ metal interface. This film transfer method enables control over the film thicknesses and layered structures of the $\mathrm{Ta}_{3} \mathrm{~N}_{5}$ photoanodes. Following modification with a $\mathrm{Co}(\mathrm{OH})_{x}$ layer acting as an oxygenevolution catalyst, a $\mathrm{Ta}_{3} \mathrm{~N}_{5}$ photoanode with a $\mathrm{NbN}_{x}$ interlayer exhibited a photocurrent of $3.5 \mathrm{~mA} \mathrm{~cm} \mathrm{~cm}^{-2}$ at $1.23 \mathrm{~V}$ vs. RHE under a simulated AM 1.5G light, a value 1.7 times that generated by a photoanode without interlayers. The present film transfer method is potentially applicable to the development of semiconductor thin films for efficient PEC energy conversion.

Received 22nd April 2016

Accepted 25th May 2016

DOI: $10.1039 / \mathrm{c} 6 \mathrm{sc} 01763 \mathrm{k}$

www.rsc.org/chemicalscience

reactive magnetron sputtering, ${ }^{14}$ electrophoretic deposition, ${ }^{15}$ and particle transfer. ${ }^{7,8,16}$

$\mathrm{Ta}_{3} \mathrm{~N}_{5}$, having a bandgap of $2.1 \mathrm{eV},{ }^{17}$ is the nitride material

The conversion of solar energy to hydrogen by photoelectrochemical (PEC) water splitting is a promising approach to meeting the increasing demand for sustainable energy. ${ }^{1,2}$ In a typical $\mathrm{p} / \mathrm{n}$ PEC device, the photoelectrode is composed of a semiconductor layer for light harvesting and a back contact layer to conduct light-induced majority charge carriers to a counter electrode. ${ }^{3,4}$ (Oxy)nitride materials, such as $\mathrm{Ta}_{3} \mathrm{~N}_{5}$, $\left(\mathrm{Ga}_{1-x} \mathrm{Zn}_{x}\right)\left(\mathrm{N}_{1-x} \mathrm{O}_{x}\right), \quad \mathrm{BaTaO}_{2} \mathrm{~N}$, and $\mathrm{LaTiO}_{2} \mathrm{~N}$, absorb over a sufficient range of visible light wavelengths in the solar spectrum and have suitable band edge positions to allow for efficient PEC water oxidation..$^{5-8}$ Several synthesis methods have been developed to configure (oxy)nitride photoelectrodes, including high-temperature nitridation of oxide layers, ${ }^{9-13}$

${ }^{a}$ Department of Chemical System Engineering, School of Engineering, The University of Tokyo, 7-3-1 Hongo, Bunkyo-ku, 113-8656 Tokyo, Japan. E-mail: domen@chemsys.t. u-tokyo.ac.jp; Fax: +81 35841 8838; Tel: +81 358411148

${ }^{b}$ Japan Technological Research Association of Artificial Photosynthetic Chemical Process (ARPChem), 2-11-9 Iwamotocho, Chiyoda-ku, 101-0032 Tokyo, Japan

'Japan Science and Technology Agency/Precursory Research for Embryonic Science and Technology (JST/PRESTO), Kawaguchi Center Building, 4-1-8, Honcho, Kawaguchi-shi, 332-0012 Saitama, Japan

${ }^{d}$ Institute of Engineering Innovation, The University of Tokyo, 2-11-16 Yayoi, Bunkyoku, 113-8656 Tokyo, Japan

$\dagger$ Electronic supplementary information (ESI) available. See DOI: $10.1039 / \mathrm{c} 6 \mathrm{sc} 01763 \mathrm{k}$ most commonly studied for PEC water splitting, because it is a simple binary nitride and has demonstrated activity for PEC water oxidation. Powder-based $\mathrm{Ta}_{3} \mathrm{~N}_{5}$ photoelectrodes can be fabricated on transparent conductive oxide layers by electrophoretic deposition. ${ }^{18}$ However, such photoelectrodes suffer from inefficient electron transfer across thick particulate $\mathrm{Ta}_{3} \mathrm{~N}_{5}$ layers and at the interface between the $\mathrm{Ta}_{3} \mathrm{~N}_{5}$ and the conductive substrate. ${ }^{19-22}$ In contrast, $\mathrm{Ta}_{3} \mathrm{~N}_{5}$ photoelectrodes grown on conductive substrates (typically Ta foils) in the form of thin films or nanorods have been reported to exhibit high photocurrent and negative onset potentials. ${ }^{23-25}$ Unfortunately, opportunities to enhance the PEC activity by tuning the film thickness and introducing multi-layer structures are restricted owing to the insufficient durability of Ta metal substrates during high-temperature treatments. The $\mathrm{Ta}_{3} \mathrm{~N}_{5}$ layer is prone to reduction to Ta-rich species (such as $\mathrm{Ta}_{5} \mathrm{~N}_{6}, \mathrm{TaN}$ and $\mathrm{Ta}_{2} \mathrm{~N}$ ) and to the formation of impurity interfacial layers resulting from the thermal diffusion of Ta from the substrate during the nitridation process. ${ }^{26-28}$

A particle transfer process has recently been developed to fabricate particulate $\mathrm{Ta}_{3} \mathrm{~N}_{5}$ photoelectrodes with excellent mechanical and electric contacts by separating the nitridation process and the deposition of contact layers. ${ }^{8,16}$ Inspired by this method, we present a thin film transfer method for $\mathrm{Ta}_{3} \mathrm{~N}_{5}$ photoelectrodes to realise precise control in film thickness and 
synthesis parameters. Using this approach, we have demonstrated that various metallic and semiconductor layers can be introduced as back contacts to improve the PEC performance of $\mathrm{Ta}_{3} \mathrm{~N}_{5}$ photoanodes.

\section{Experimental section}

\section{Materials preparation}

The procedure used to synthesize $\mathrm{Ta}_{3} \mathrm{~N}_{5}$ by thin film transfer is presented in Fig. 1. Single-crystalline Si wafers (Nilaco Co.) were cut into specimens with dimensions of $1 \times 1 \mathrm{~cm}$. These $\mathrm{Si}$ substrates were then treated by sequential sonication in acetone, 2-propanol and Milli-Q water $(18.2 \mathrm{~m} \Omega \mathrm{cm})$, and the cleaned Si substrates were directly used, without HF etching to remove the surface native $\mathrm{SiO}_{2}$. Thin Ta films, with thicknesses ranging from 150 to $800 \mathrm{~nm}$, were deposited on these Si substrates by radio-frequency (RF) magnetron sputtering (ULVAC, MNS-2000-RFG3) at a substrate temperature of $500{ }^{\circ} \mathrm{C}$. The working pressure and the output power of the Ar plasma during this process were $1.0 \times 10^{-1} \mathrm{~Pa}$ and $100 \mathrm{~W}$, respectively. The deposition rate of the Ta film was $25 \mathrm{~nm} \min ^{-1}$. The resulting $\mathrm{Ta} / \mathrm{Si}$ samples were oxidised in a muffle furnace at $700{ }^{\circ} \mathrm{C}$ for $2 \mathrm{~h}$ to form $\mathrm{Ta}_{2} \mathrm{O}_{5}$ films, and these $\mathrm{Ta}_{2} \mathrm{O}_{5} / \mathrm{Si}$ specimens were subsequently nitrided in a flow of gaseous $\mathrm{NH}_{3}$ $(100 \mathrm{sccm})$ at $900{ }^{\circ} \mathrm{C}$ for $2 \mathrm{~h}$ to produce $\mathrm{Ta}_{3} \mathrm{~N}_{5}$ thin films on the $\mathrm{Si}$ substrates. Ta $(150 \mathrm{~nm})$ and $\mathrm{Ti}$ (approximately $5 \mu \mathrm{m}$ ) layers were then sputtered on top of the as-nitrided $\mathrm{Ta}_{3} \mathrm{~N}_{5}$ thin films. In some cases, the Ta layer was replaced with $\mathrm{Nb}, \mathrm{Ti}, \mathrm{Zr}$ (containing $4.5 \% \mathrm{Hf}$ ) or $\mathrm{Mg}$ and different contact materials were investigated, as described in the ESI. $\uparrow$ The $\mathrm{Ta}_{3} \mathrm{~N}_{5} / \mathrm{Ta} / \mathrm{Ti}$ films could be completely peeled away from the Si substrates by mechanical exfoliation. The transferred films were cleaned with an $\mathrm{HF} /$ $\mathrm{HNO}_{3} / \mathrm{H}_{2} \mathrm{O}(1 / 2 / 7, \mathrm{v} / \mathrm{v})$ solution for $10 \mathrm{~s}$. Subsequently, the back side of each $\mathrm{Ta}_{3} \mathrm{~N}_{5} / \mathrm{Ta} / \mathrm{Ti}$ sample was attached to a glass plate with carbon tape and connected to an electrical wire using indium solder. The electrode area exposed to the electrolyte solution was defined by applying a water-proof epoxy resin, and the typical exposed electrode area was approximately $0.2 \mathrm{~cm}^{2}$.

A layer of $\mathrm{Co}(\mathrm{OH})_{x}$ was deposited on the surface of each $\mathrm{Ta}_{3} \mathrm{~N}_{5}$ photoelectrode prior to the photoelectrochemical (PEC) measurements. An aqueous $2.5 \mathrm{~mL} \mathrm{NaOH}(50 \mathrm{mM})$ solution was added to $10 \mathrm{~mL}$ of an aqueous $\mathrm{Co}\left(\mathrm{NO}_{3}\right)_{2}(6.3 \mathrm{mM})$ solution, and

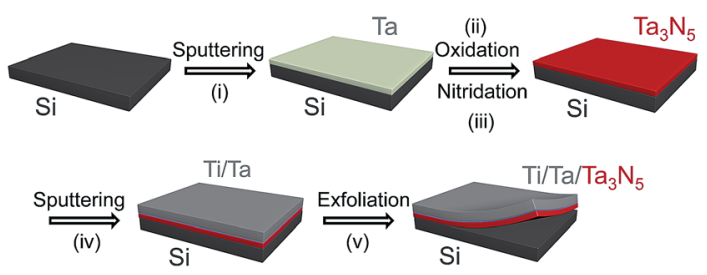

Fig. 1 Schematic depicting the processes involved in the thin film transfer method. (i) A Ta thin film is deposited on the Si substrate by sputtering, (ii) the Ta film is oxidised to $\mathrm{Ta}_{2} \mathrm{O}_{5}$ on the $\mathrm{Si}$ substrate, (iii) the $\mathrm{Ta}_{2} \mathrm{O}_{5} / \mathrm{Si}$ is converted to $\mathrm{Ta}_{3} \mathrm{~N}_{5} / \mathrm{Si}$ by nitridation in a flow of gaseous $\mathrm{NH}_{3}$, (iv) $\mathrm{Ta}$ and $\mathrm{Ti}$ layers are sequentially sputtered on the surface of the $\mathrm{Ta}_{3} \mathrm{~N}_{5} / \mathrm{Si}$, and $(\mathrm{v})$ the resulting $\mathrm{Ta}_{3} \mathrm{~N}_{5} / \mathrm{Ta} / \mathrm{Ti}$ is mechanically exfoliated from the Si substrate and used as a photoelectrode. the as-prepared $\mathrm{Ta}_{3} \mathrm{~N}_{5}$ photoelectrode was immersed in the mixture for $1 \mathrm{~h}$. As the initial blue solution gradually transitioned to a yellow colloidal suspension, a thin layer of $\mathrm{Co}(\mathrm{OH})_{x}$ was formed on the surface of the electrode.

\section{Characterization}

Scanning electron microscopy (SEM; S-4700, Hitachi), scanning transmission electron microscopy and transmission electron microscopy (STEM, TEM; JEM-2800, JEOL) in conjunction with energy-dispersive X-ray spectroscopy (EDS; EX-24055JGT, JEOL) were used to characterise the morphologies and cross-sectional structures of the $\mathrm{Ta}_{3} \mathrm{~N}_{5}$ thin films. X-ray diffraction (XRD; Rigaku Ultima III) patterns were acquired using $\mathrm{Cu} \mathrm{K} \alpha$ radiation $(\lambda=0.15405 \mathrm{~nm}, 40 \mathrm{mV}$ and $40 \mathrm{~mA})$ and X-ray photoelectron spectroscopy (XPS; JEOL, JPS-90SX) was performed with $\mathrm{Mg} \mathrm{K} \alpha$ radiation $(8 \mathrm{kV}$ and $10 \mathrm{~mA})$.

\section{Photoelectrochemical measurements}

The PEC properties of the $\mathrm{Ta}_{3} \mathrm{~N}_{5}$ photoanodes were assessed in a three-electrode cell controlled by a potentiostat (Hokuto Denko, HSV-110). An Ag/AgCl (in saturated $\mathrm{KCl}$ aq.) electrode and a Pt wire were used as the reference and counter electrodes, respectively. The potential against the $\mathrm{Ag} / \mathrm{AgCl}$ reference electrode $\left(E_{\mathrm{Ag} / \mathrm{AgCl}}\right)$ was converted to the potential with respect to a reversible hydrogen electrode $\left(E_{\mathrm{RHE}}\right)$ using the Nernst equation below.

$$
E_{\mathrm{RHE}}=E_{\mathrm{Ag} / \mathrm{AgCl}}+0.197 \mathrm{~V}+0.059 \times \mathrm{pH}
$$

PEC measurements were performed in an aqueous solution of potassium phosphate (KPi, 0.5 M, pH 13) under a simulated AM 1.5G light source (San-EI Electric, XES-40S2-CE). The $\mathrm{H}_{2}$ and $\mathrm{O}_{2}$ gas yields from the counter electrode and a $\mathrm{Ta}_{3} \mathrm{~N}_{5}$ photoanode held at $1.23 \mathrm{~V} v s$. RHE were accumulated in an air-tight, three-electrode PEC cell and quantified using a micro gas chromatograph (Agilent, 3000A, Micro GC).

\section{Results and discussion}

Fig. 2 presents XRD patterns for the thin film samples before nitridation, after nitridation, and after film transfer. Fig. 2(a) demonstrates that a crystalline $\mathrm{Ta}_{2} \mathrm{O}_{5}$ film was formed by oxidising the metallic Ta film at $700{ }^{\circ} \mathrm{C}$, while Fig. 2(b) shows that a $\mathrm{Ta}_{3} \mathrm{~N}_{5}$ film with an orthorhombic phase was formed on the $\mathrm{Si}$ substrate by nitridation at $900{ }^{\circ} \mathrm{C}$. The crystalline $\mathrm{Ta}_{3} \mathrm{~N}_{5}$ films were evidently preserved during the film transfer process (Fig. 2(c)). $\mathrm{Ta}_{2} \mathrm{~N}$ and $\mathrm{Ta}_{5} \mathrm{~N}_{6}$, which are both typical impurity phases in $\mathrm{Ta}_{3} \mathrm{~N}_{5}$ films grown on Ta metal substrates, ${ }^{26,27}$ were not observed in our $\mathrm{Ta}_{3} \mathrm{~N}_{5}$ films having thicknesses of 570, 1120, and $1620 \mathrm{~nm}$, as shown in Fig. S1 in the ESI. $\dagger$ This suggests that reduction of the $\mathrm{Ta}_{3} \mathrm{~N}_{5}$ phase during the nitridation process was inhibited owing to the absence of the underlying Ta metal. Complete transformation to $\mathrm{Ta}_{3} \mathrm{~N}_{5}$ was achieved even in the case of the especially thick $\mathrm{Ta}_{3} \mathrm{~N}_{5}$ films $(>1000 \mathrm{~nm})$. This was likely due to the formation of a porous structure that facilitated penetration of $\mathrm{N}$ or $\mathrm{NH}$ species throughout the film. 


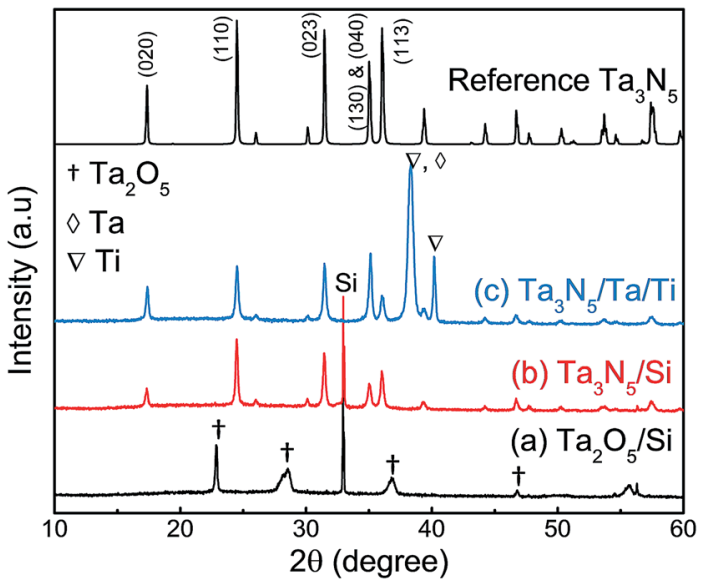

Fig. 2 XRD patterns for (a) $\mathrm{Ta}_{2} \mathrm{O}_{5} / \mathrm{Si}$ and (b) $\mathrm{Ta}_{3} \mathrm{~N}_{5} / \mathrm{Si}$ obtained from the nitridation of $\mathrm{Ta}_{2} \mathrm{O}_{5} / \mathrm{Si}$, and (c) $\mathrm{Ta}_{3} \mathrm{~N}_{5} / \mathrm{Ta} / \mathrm{Ti}$ after the transfer process. The standard pattern for the $\mathrm{Ta}_{3} \mathrm{~N}_{5}$ phase (PDF\# 89-5200) is displayed at the top as a reference.

Fig. 3(a) shows a cross-sectional SEM image of a $\mathrm{Ta}_{3} \mathrm{~N}_{5}$ film on a $\mathrm{Si}$ substrate. This porous $\mathrm{Ta}_{3} \mathrm{~N}_{5}$ film was formed by nitridation as the three $\mathrm{O}^{2-}$ anions in the original $\mathrm{Ta}_{2} \mathrm{O}_{5}$ film were replaced by two $\mathrm{N}^{3-}$ anions. From the cross-sectional images (Fig. 3(b) and (c)), it is evident that the thickness of the $\mathrm{Ta}_{3} \mathrm{~N}_{5}$ film $(570 \mathrm{~nm})$ remained unchanged during the film transfer process. The multi-layer $\mathrm{Ta}_{3} \mathrm{~N}_{5} / \mathrm{Ta} / \mathrm{Ti}$ structure was further confirmed by the cross-sectional EDS maps presented in Fig. 3(d) and (e). Because the sputtered $\mathrm{Ta} / \mathrm{Ti}$ layer resulted in rigid contact with the $\mathrm{Ta}_{3} \mathrm{~N}_{5}$ layer, the $\mathrm{Ta}_{3} \mathrm{~N}_{5}$ film was readily exfoliated from the Si substrate without damaging the layered structure of the $\mathrm{Ta}_{3} \mathrm{~N}_{5} / \mathrm{Ta} / \mathrm{Ti}$ film. However, $\mathrm{Ta}_{3} \mathrm{~N}_{5}$ films thinner than $300 \mathrm{~nm}$ could not be peeled away from the Si substrate without breaking. It is believed that the presence of significant porosity at the film/substrate interface plays a key role in successful film transfer, given the correlation between the porosity and thickness of $\mathrm{Ta}_{3} \mathrm{~N}_{5}$ thin films. ${ }^{19}$ The metallic Ta and Ti layers acted as a back contact and a conductive support for the $\mathrm{Ta}_{3} \mathrm{~N}_{5}$ films, respectively. The transferred $\mathrm{Ta}_{3} \mathrm{~N}_{5}$ film was flexible (Fig. 3(f)) and had a rough surface originating from the porosity of the $\mathrm{Ta}_{3} \mathrm{~N}_{5}$ (Fig. $3(\mathrm{~g})$ ). XPS analysis of the $\mathrm{Ta}_{3} \mathrm{~N}_{5}$ films before and after transfer (Fig. S2 $\dagger$ ) revealed that no Si species were present on the surface of the $\mathrm{Ta}_{3} \mathrm{~N}_{5}$ film after thin film transfer. This result demonstrates a lack of Si diffusion into the bulk of the $\mathrm{Ta}_{3} \mathrm{~N}_{5}$ film, owing to the stability of the Si substrates during the high temperature nitridation.

In order to examine the structural properties of the $\mathrm{Ta}_{3} \mathrm{~N}_{5}$ film, a dark-field (DF) STEM image (Fig. 2(h)) of a cross section close to the $\mathrm{Ta}_{3} \mathrm{~N}_{5} / \mathrm{Ta}$ interface was acquired. The bright contrast in this DF-STEM image indicates a highly porous structure for the transferred $\mathrm{Ta}_{3} \mathrm{~N}_{5}$ film. The average size of the pores between the $\mathrm{Ta}_{3} \mathrm{~N}_{5}$ grains was approximately $20 \mathrm{~nm}$, and thus was likely responsible for the high surface area of the $\mathrm{Ta}_{3} \mathrm{~N}_{5}$ photoelectrodes. The average grain sizes of $\mathrm{Ta}_{3} \mathrm{~N}_{5}$ crystals were estimated from the zone-axis TEM image (Fig. 2(i)) to be in the range of 20 to $50 \mathrm{~nm}$, a value that is much smaller than the film thickness $(570 \mathrm{~nm})$. The TEM fast Fourier transform (FFT) diffraction patterns also demonstrate disorder in the
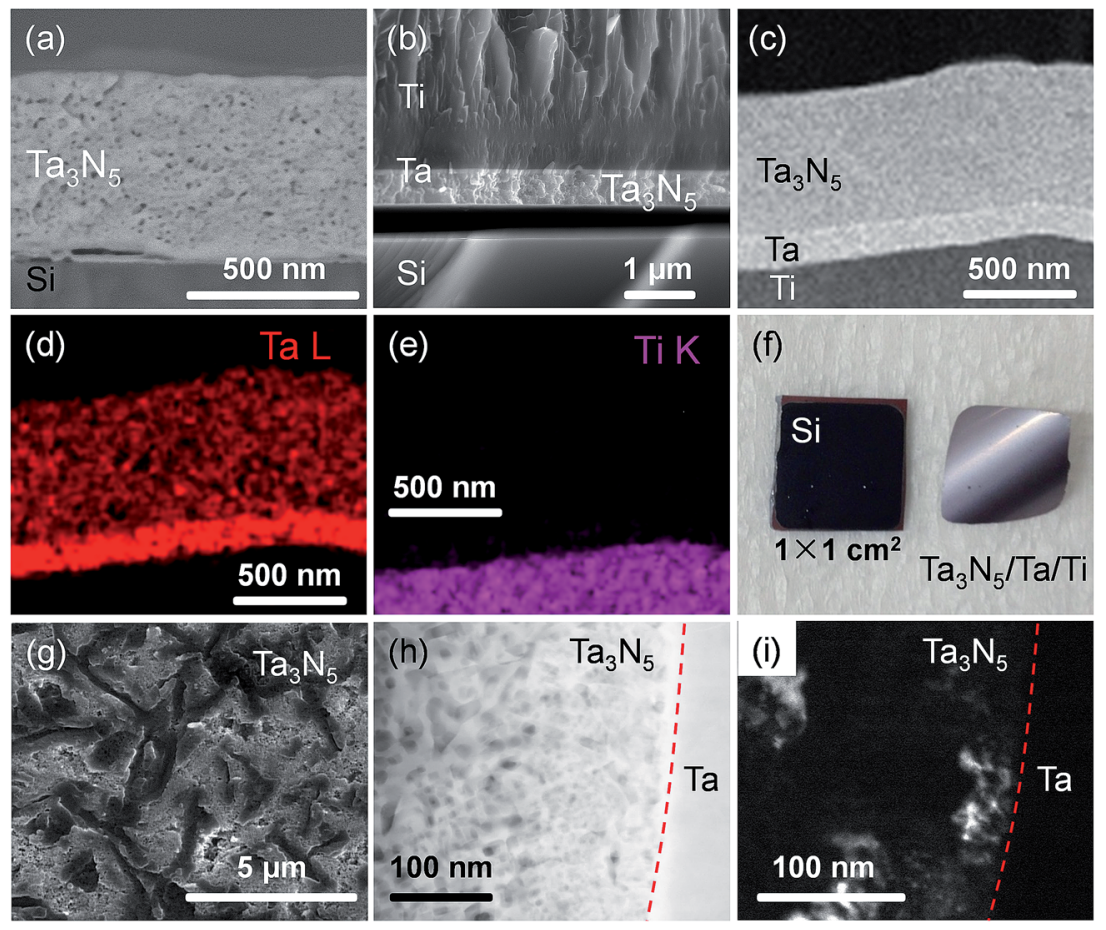

Fig. 3 Cross-sectional SEM images of (a) $\mathrm{Ta}_{3} \mathrm{~N}_{5} / \mathrm{Si}$ and (b) $\mathrm{Ti} / \mathrm{Ta} / \mathrm{Ta}_{3} \mathrm{~N}_{5} / \mathrm{Si}$, (c) cross-sectional STEM image of transferred Ta $3 \mathrm{~N}_{5} / \mathrm{Ta} / \mathrm{Ti}$, EDS maps for (d) Ta and (e) Ti taken from the STEM image in panel (c), (f) digital photographs of a $\mathrm{Ta}_{3} \mathrm{~N}_{5} / \mathrm{Ta} / \mathrm{Ti}$ sample transferred from a Si substrate, (g) topview SEM image of a $\mathrm{Ta}_{3} \mathrm{~N}_{5} / \mathrm{Ta} / \mathrm{Ti}$ sample, and dark-field (h) STEM and (i) zone-axis TEM images of a $\mathrm{Ta}_{3} \mathrm{~N}_{5} / \mathrm{Ta} / \mathrm{Ti}_{\mathrm{i}}$ sample near the Ta $\mathrm{N}_{5} / \mathrm{Ta}$ interface. 
arrangement of the $\mathrm{Ta}_{3} \mathrm{~N}_{5}$ grains (Fig. $\mathrm{S} 3 \dagger$ ). Hence, a number of grain boundaries were present in the $\mathrm{Ta}_{3} \mathrm{~N}_{5}$ film. However, the thin film was in intimate contact with the polycrystalline Ta layer prepared by magnetron sputtering. Owing to the matching of the work function of metallic $\mathrm{Ta}(4.3 \mathrm{eV})^{29}$ and the flat band potential of the $\mathrm{Ta}_{3} \mathrm{~N}_{5}$ electrode $(0.02 \mathrm{~V}$ vs. RHE, Fig. S4 $\dagger$ ), an ohmic contact was expected to be present at the $\mathrm{Ta}_{3} \mathrm{~N}_{5} / \mathrm{Ta}$ interface. As a result, the energy barrier for the transport of photogenerated electrons across the $\mathrm{Ta}_{3} \mathrm{~N}_{5} / \mathrm{Ta}$ interface was minimized.

Current-potential curves for $\mathrm{Ta}_{3} \mathrm{~N}_{5}$ photoanodes with film thicknesses of 570, 1120 and $1620 \mathrm{~nm}$ were obtained under simulated AM 1.5G light and are presented in Fig. 4(a). A photocurrent density of $2.0 \mathrm{~mA} \mathrm{~cm} \mathrm{~cm}^{-2}$ at $1.23 \mathrm{~V} v s$. RHE was observed in the case of the $\mathrm{Ta}_{3} \mathrm{~N}_{5}(570 \mathrm{~nm}) / \mathrm{Ta} / \mathrm{Ti}$ photoelectrode modified with a cobalt-based oxygen-evolution catalyst. The faradaic efficiency for PEC water oxidation reaction was determined by quantifying the $\mathrm{O}_{2}$ evolved at the $\mathrm{Ta}_{3} \mathrm{~N}_{5} / \mathrm{Ta} / \mathrm{Ti}$ photoanode held at $1.23 \mathrm{~V}$ vs. $\mathrm{RHE}$ and the $\mathrm{H}_{2}$ evolved at the $\mathrm{Pt}$ counter electrode by gas chromatography (Fig. 4(b)). The faradaic efficiency of almost unity indicates that the photoanodic current generated by the $\mathrm{Ta}_{3} \mathrm{~N}_{5}$ photoelectrode is primarily attributable to the $\mathrm{O}_{2}$ evolution process. The incident photonto-current conversion efficiency (IPCE) spectrum (Fig. S5†) demonstrates that the $\mathrm{Ta}_{3} \mathrm{~N}_{5}$ film photoanodes were capable of utilising visible light up to $600 \mathrm{~nm}$, corresponding to the bandgap of $\mathrm{Ta}_{3} \mathrm{~N}_{5}(2.1 \mathrm{eV})$, for PEC water oxidation. However, because of the porous nature of the $\mathrm{Ta}_{3} \mathrm{~N}_{5}$ films, the photoelectrode surface was not fully covered with the $\mathrm{Co}(\mathrm{OH})_{x}$ layer (Fig. S6 $\dagger$ ). As a result, the $\mathrm{O}_{2}$ evolution rate decreased gradually over time owing to the photocorrosion of the $\mathrm{Ta}_{3} \mathrm{~N}_{5}$ films.

A significant decrease in the photocurrent density was associated with increases in the film thicknesses of the $\operatorname{Ta}_{3} \mathrm{~N}_{5}$ photoelectrodes. The probability of charge carrier recombination in thicker $\mathrm{Ta}_{3} \mathrm{~N}_{5}$ films is expected to be higher, given the large number of grain boundaries acting as electron-hole recombination centres and the long diffusion distances for both holes and electrons. It should be noted that $\mathrm{Ta}_{3} \mathrm{~N}_{5}$ films thinner than $300 \mathrm{~nm}$ could not be prepared by film transfer from $\mathrm{Si}$ substrates as described above. ${ }^{19}$ Therefore, a film thickness of approximately $600 \mathrm{~nm}$ was the optimum value for the $\mathrm{Ta}_{3} \mathrm{~N}_{5}$ photoanodes prepared by thin film transfer. This thickness is consistent with the layer thickness reported for $\mathrm{Ta}_{3} \mathrm{~N}_{5}$ photoelectrodes with exhibiting superior PEC performance. ${ }^{\mathbf{1 9 , 2 4}}$

The thin film transfer method allows tuning of the thickness of the $\mathrm{Ta}_{3} \mathrm{~N}_{5}$ film to arbitrary values above approximately $550 \mathrm{~nm}$. Another and potentially more important feature of the film transfer technique is the possibility of obtaining the desired multi-layer structure in the $\mathrm{Ta}_{3} \mathrm{~N}_{5}$ film. It is conceptually possible to introduce doping, catalytic, protective, and/or sacrificial template layers at the front and/or rear sides of the $\mathrm{Ta}_{3} \mathrm{~N}_{5}$ film by depositing such functional layers before and/or after formation of either the Ta or $\mathrm{Ta}_{2} \mathrm{O}_{5}$ layers. It is also feasible to use materials other than Ta, such as metals, sulphides, and nitrides, as contact layers after the nitridation. As an example, current-potential curves for $\mathrm{Ta}_{3} \mathrm{~N}_{5}$ photoelectrodes with different metallic contact layers ( $\mathrm{Ta}, \mathrm{Nb}, \mathrm{Ti}, \mathrm{Zr}$ and $\mathrm{Mg}$ ) are shown in Fig. 5(a). It was found that $\mathrm{Ta}_{3} \mathrm{~N}_{5}$ photoelectrodes with $\mathrm{Ta}$ and $\mathrm{Nb}$ back contacts showed higher photocurrents than those with $\mathrm{Mg}$ and $\mathrm{Zr}$ back contacts although all the metallic layers were expected to form an ohmic contact with the $\mathrm{Ta}_{3} \mathrm{~N}_{5}$ films. A Mg or $\mathrm{Zr}$ contact layer with small work function (Table $\mathrm{S} 1$ in ESI $\dagger$ ) was probably too sensitive to oxygen to form an ideal ohmic junction, resulting in a poor PEC performance. In addition, $\mathrm{NbN}_{x}, \mathrm{TiN}_{x}$ and $\mathrm{CdS}$ were introduced as back contact materials for $\mathrm{Ta}_{3} \mathrm{~N}_{5}$ photoelectrodes (Fig. 5(b) and S7 $\dagger$ ). $\mathrm{A} \mathrm{Ta}_{3} \mathrm{~N}_{5} /$ $\mathrm{NbN}_{x} /$ Ta photoelectrode with a $\mathrm{NbN}_{x}$ back contact generated a higher current density $\left(3.5 \pm 0.2 \mathrm{~mA} \mathrm{~cm}^{-2}\right.$ at $1.23 \mathrm{~V} v s$. RHE) than a $\mathrm{Ta}_{3} \mathrm{~N}_{5} / \mathrm{Ta}$ photoelectrode $\left(2.2 \pm 0.2 \mathrm{~mA} \mathrm{~cm}^{-2}\right)$, as shown in Fig. S8, $\uparrow$ while $\operatorname{TiN}_{x}$ and CdS back contacts lowered the PEC activity. The photocurrent of the $\mathrm{Ta}_{3} \mathrm{~N}_{5} / \mathrm{NbN}_{x} / \mathrm{Ta}$ photoanode decayed with time, similarly to the $\mathrm{Ta}_{3} \mathrm{~N}_{5} / \mathrm{NbN}_{x} / \mathrm{Ta}$ photoanode, because the interlayer did not suppress photocorrosion of the $\mathrm{Ta}_{3} \mathrm{~N}_{5}$ surface. In addition, the effects of the back contact materials on the properties of the $\mathrm{Ta}_{3} \mathrm{~N}_{5}$ films are not fully understood at present. However, it is clear that certain back contact materials can promote PEC oxygen evolution on $\mathrm{Ta}_{3} \mathrm{~N}_{5}$ thin films. In future work, this film transfer process is expected to allow clarification of the promotional effect of interlayers on the PEC properties of $\mathrm{Ta}_{3} \mathrm{~N}_{5}$ films by taking advantage of the controllability of the layered structure.
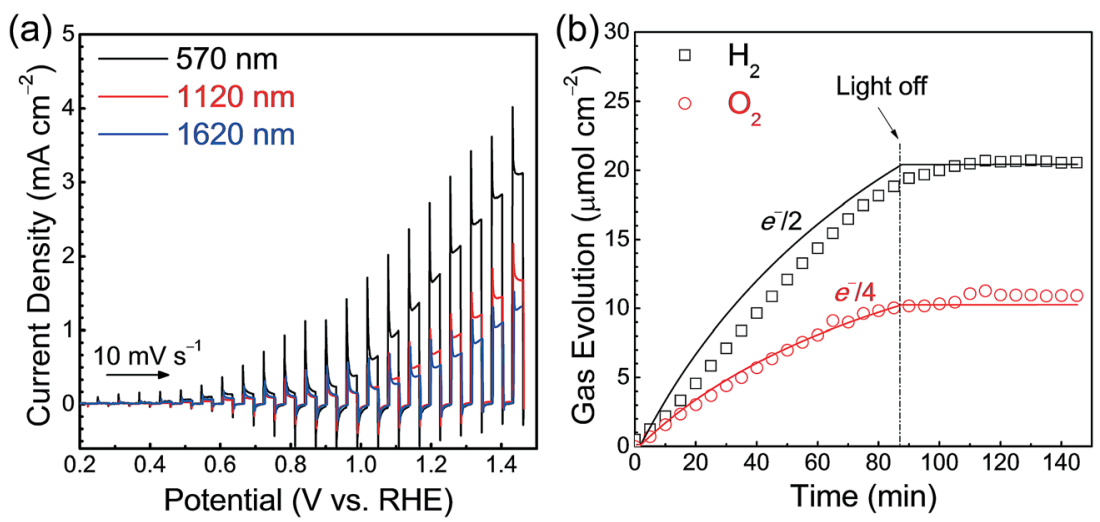

Fig. 4 (a) Current-potential curves obtained from $\mathrm{Ta}_{3} \mathrm{~N}_{5}$ photoanodes with different film thicknesses under simulated AM 1.5G light, and (b) time course of $\mathrm{O}_{2}$ (open circles) and $\mathrm{H}_{2}$ (open squares) gas evolution from a Ta $\mathrm{N}_{5}(570 \mathrm{~nm}) / \mathrm{Ta} / \mathrm{Ti}$ photoanode held at $1.23 \mathrm{~V}$ vs. RHE and a Pt counter electrode, respectively, under simulated AM 1.5G light. Solid curves represent the total charges estimated from the photocurrent. 

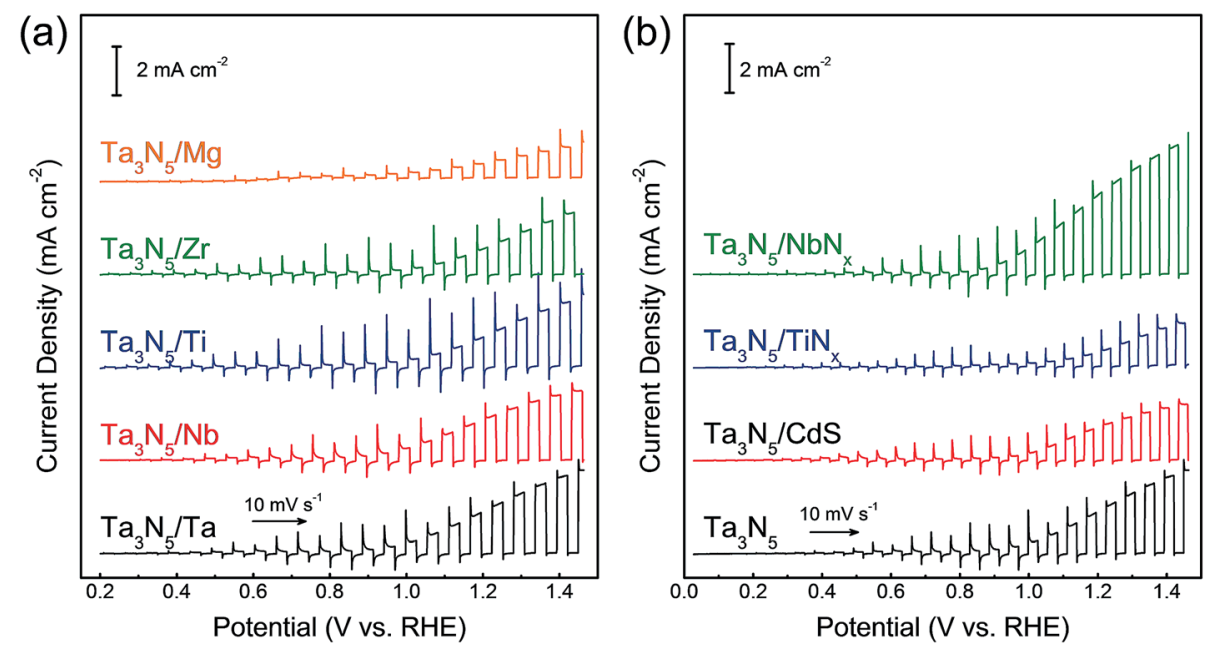

Fig. 5 Current-potential curves obtained from $\mathrm{Ta}_{3} \mathrm{~N}_{5}$ photoanodes with different back contact layers. (a) $\mathrm{Ta} \mathrm{N}_{3} \mathrm{~N}_{5} / \mathrm{M} / \mathrm{Ti}(\mathrm{M}=\mathrm{Ta}, \mathrm{Nb}, \mathrm{Ti}, \mathrm{Zr}$ and $\mathrm{Mg}$ ), and (b) $\mathrm{Ta}_{3} \mathrm{~N}_{5} / \mathrm{N} / \mathrm{Ta} / \mathrm{Ti}\left(\mathrm{N}=\mathrm{NbN}_{x}, \mathrm{TiN}_{x}\right.$ and $\mathrm{CdS}$ ).

\section{Conclusions}

A thin film transfer method for the fabrication of $\mathrm{Ta}_{3} \mathrm{~N}_{5}$ thin films having different thicknesses and back contact layers has been demonstrated. The inertness of the Si substrates allowed the synthesis of pure, crystalline $\mathrm{Ta}_{3} \mathrm{~N}_{5}$ films via the thermal nitridation of sputtered Ta films, and also resulted in weak adhesion at the $\mathrm{Ta}_{3} \mathrm{~N}_{5} / \mathrm{Si}$ interface that promoted the film transfer process. This new preparation method allows optimization of the PEC performance of $\mathrm{Ta}_{3} \mathrm{~N}_{5}$ thin film photoanodes by controlling the film thickness. $\mathrm{Ta}_{3} \mathrm{~N}_{5}(570 \mathrm{~nm}) / \mathrm{Ta} / \mathrm{Ti}$ photoanodes generated a photocurrent of $2.0 \mathrm{~mA} \mathrm{~cm}^{-2}$ at $1.23 \mathrm{~V} v s$. RHE under simulated AM 1.5G light, while thicker films produced lower photocurrents because of the longer charge carrier migration distances and the greater concentration of grain boundaries. The photocurrent at $1.23 \mathrm{~V} v s$. RHE could be further enhanced to $3.5 \mathrm{~mA} \mathrm{~cm}{ }^{-2}$ by modification of the back contact layer applied to the transferred $\mathrm{Ta}_{3} \mathrm{~N}_{5}$ film.

This film transfer procedure circumvents current strict requirements for the conductive substrates that can be employed during vigorous annealing treatments, enabling the preparation and the transfer of semiconductor thin films from various inert substrates. Therefore, the new fabrication strategy presented herein has the potential to allow the preparation of thin film photoelectrodes composed of materials such as $\alpha$ $\mathrm{Fe}_{2} \mathrm{O}_{3}, \mathrm{BiVO}_{4}$ and $\mathrm{BaTaO}_{2} \mathrm{~N}$ for applications in PEC water splitting and/or PEC solar cells.

\section{Acknowledgements}

This work was financially supported by Grants-in-Aid for Specially Promoted Research (No. 23000009), for Young Scientists (A) (No. 15H05494) and Young Scientists (B) (No. 5K17895) of Japan Society for the Promotion of Science (JSPS). This work was partly supported by the Artificial Photosynthesis Project (ARPChem) of the New Energy and Industrial Technology Development Organization (NEDO). Part of this work was conducted at the Research Hub for Advanced Nano Characterization at the University of Tokyo, under the support of the "Nanotechnology Platform" (project No. 12024046) of the Ministry of Education, Culture, Sports, Science and Technology (MEXT), Japan. The authors thank Dr Qian Wang, Dr Miao Zhong, Dr Taro Yamada and Mr Yutaka Sasaki in the University of Tokyo for SEM characterisation and discussions.

\section{References}

1 M. Grätzel, Nature, 2001, 414, 338-344.

2 A. Fujishima and K. Honda, Nature, 1972, 238, 37-38.

3 A. J. Nozik, Annu. Rev. Phys. Chem., 1978, 29, 189-222.

4 M. G. Walter, E. L. Warren, J. R. McKone, S. W. Boettcher, Q. Mi, E. A. Santori and N. S. Lewis, Chem. Rev., 2010, 110, 6446-6473.

5 T. Hisatomi, J. Kubota and K. Domen, Chem. Soc. Rev., 2014, 43, 7520-7535.

6 M. Zhong, Y. Ma, P. Oleynikov, K. Domen and J.-J. Delaunay, Energy Environ. Sci., 2014, 7, 1693-1699.

7 K. Ueda, T. Minegishi, J. Clune, M. Nakabayashi, T. Hisatomi, H. Nishiyama, M. Katayama, N. Shibata, J. Kubota, T. Yamada and K. Domen, J. Am. Chem. Soc., 2015, 137, 2227-2230.

8 T. Minegishi, N. Nishimura, J. Kubota and K. Domen, Chem. Sci., 2013, 4, 1120-1124.

9 H. X. Dang, N. T. Hahn, H. S. Park, A. J. Bard and C. B. Mullins, J. Phys. Chem. C, 2012, 116, 19225-19232.

10 S. Khan, M. J. M. Zapata, M. B. Pereira, R. V. Goncalves, L. Strizik, J. Dupont, M. J. L. Santos and S. R. Teixeira, Phys. Chem. Chem. Phys., 2015, 17, 23952-23962.

11 C. Wang, T. Hisatomi, T. Minegishi, Q. Wang, M. Zhong, M. Katayama, J. Kubota and K. Domen, J. Phys. Chem. C, 2016, DOI: 10.1021/acs.jpcc.5b11564.

12 G. J. Liu, J. Y. Shi, F. X. Zhang, Z. Chen, J. F. Han, C. M. Ding, S. S. Chen, Z. L. Wang, H. X. Han and C. Li, Angew. Chem., Int. Ed., 2014, 53, 7295-7299. 
13 M. X. Li, W. J. Luo, D. P. Cao, X. Zhao, Z. S. Li, T. Yu and Z. G. Zou, Angew. Chem., Int. Ed., 2013, 52, 11016-11020.

14 D. Yokoyama, H. Hashiguchi, K. Maeda, T. Minegishi, T. Takata, R. Abe, J. Kubota and K. Domen, Thin Solid Films, 2011, 519, 2087-2092.

15 M. Higashi, K. Domen and R. Abe, J. Am. Chem. Soc., 2013, 135, 10238-10241.

16 J. Seo, T. Takata, M. Nakabayashi, T. Hisatomi, N. Shibata, T. Minegishi and K. Domen, J. Am. Chem. Soc., 2015, 137, 12780-12783.

17 W. J. Chun, A. Ishikawa, H. Fujisawa, T. Takata, J. N. Kondo, M. Hara, M. Kawai, Y. Matsumoto and K. Domen, J. Phys. Chem. B, 2003, 107, 1798-1803.

18 M. Higashi, K. Domen and R. Abe, Energy Environ. Sci., 2011, 4, 4138-4147.

19 B. A. Pinaud, P. C. K. Vesborg and T. F. Jaramillo, J. Phys. Chem. C, 2012, 116, 15918-15924.

20 A. Dabirian and R. van de Krol, Chem. Mater., 2015, 27, 708715.
21 A. Ziani, E. Nurlaela, D. S. Dhawale, D. A. Silva, E. Alarousu, O. F. Mohammed and K. Takanabe, Phys. Chem. Chem. Phys., 2015, 17, 2670-2677.

22 J. M. Morbec, I. Narkeviciute, T. F. Jaramillo and G. Galli, Phys. Rev. B, 2014, 90, 155204.

23 G. Liu, S. Ye, P. Yan, F. Xiong, P. Fu, Z. Wang, Z. Chen, J. Shi and C. Li, Energy Environ. Sci., 2016, 9, 1327-1334.

24 Y. Li, L. Zhang, A. Torres-Pardo, J. M. González-Calbet, Y. Ma, P. Oleynikov, O. Terasaki, S. Asahina, M. Shima, D. Cha, L. Zhao, K. Takanabe, J. Kubota and K. Domen, Nat. Commun., 2013, 4, 2566.

25 C. Zhen, L. Wang, G. Liu, G. Q. Lu and H.-M. Cheng, Chem. Commun., 2013, 49, 3019-3021.

26 B. A. Pinaud, A. Vailionis and T. F. Jaramillo, Chem. Mater., 2014, 26, 1576-1582.

27 Y. Li, T. Takata, D. Cha, K. Takanabe, T. Minegishi, J. Kubota and K. Domen, Adv. Mater., 2013, 25, 125-131.

28 T. Nobuzo, Jpn. J. Appl. Phys., 1971, 10, 248-259.

29 H. L. Skriver and N. M. Rosengaard, Phys. Rev. B: Condens. Matter Mater. Phys., 1992, 46, 7157-7168. 